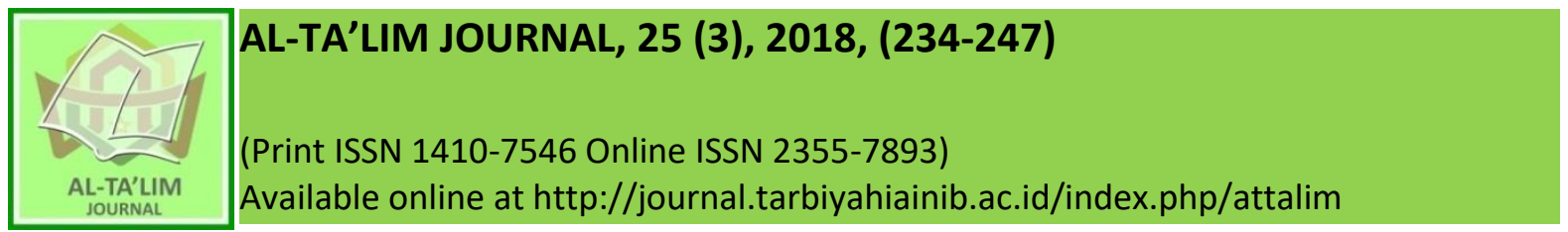

\title{
Teaching Quantitative Research Method with Three Methods of Learning
}

Received: $07^{\text {th }}$ July 2018; Revised: $04^{\text {th }}$ September 2018; Accepted: $26^{\text {th }}$ November 2018

Permalink/DOI: http://dx.doi.org/10.15548/jt.v25i3.394

\section{Muhammad Haviz*) \\ Institut Agama Islam Negeri \\ Batusangkar, Indonesia \\ E-mail: haviz80@yahoo.co.id}

\section{Ika Metiza Maris}

Institut Agama Islam Negeri

Batusangkar, Indonesia

E-mail:

kametizamaris@iainbatusangkar.ac.id

\section{*) Corresponding Author}

\begin{abstract}
This study aims to investigated the effect of lecturediscussion (LD), direct instruction (DI)and guide inqury (GI) to students'achievement on quantitative design research. An experimental comparison group post-test only designwas used to prove the hypothesis there is a significant difference of students'achievement onundergraduate biology education class (BEC) and master's economic class (EC)with the using of LD, DI and GI.This study used34 BECs' student and 26 ECs' student who take quantitative research courses in the academic year 2016-2017.The students' achievement was measured by instrument of Research based Learning (RbL). The collected data has been analyzed by using descriptive statistics, and Chi-Square test to determine the comparison in both treatment of classes. The result of this study has shown that $\chi^{2}$ scores of $\operatorname{LD}(71.276)$ and $\chi^{2}$ scores of $\mathrm{DI}(203.12)>\chi^{2}$ table $\alpha(0.05 ; 0.01)(15.507 ; 20.090)$. At the using of GI, the quality for students' achievement scores on BEC is better than EC (standard vs. approaching standard). In conclusion, there was significant difference of students'achievement onBEC and EC with the using of LD, DI and GI.
\end{abstract}

Keywords: Lecture discussion; direct instruction; guide inquiry; quantitative research

How to cite: Haviz, M., \& Maris, I. (2018). Teaching quantitative research method with three methods of learning. Al-Ta Lim Journal, 25(3). doi:http://dx.doi.org/10.15548/jt.v25i3.394

\section{INTRODUCTION}

Quality research, teaching and performances in the academic field influence the quality of the university (European University Association, 2016; Cadez, Dimovski, \& Groff, 2017). Research will have implications on teaching in college (Brew, 2010), because research is a process to collect data about a topic or problem, where the data can be used by lecturers to improve knowledge and practice in teaching (Creswell, 2012). While the teaching approaches used by lecturers influence the way students learn (Beausaert, Segers, \& Wiltink, 2013). The use of teaching strategies used by lecturers also affects the results of student learning and satisfaction (Gómez, Martínez, \& Miranda, 2015; Healey, 2007). Therefore lecturers should also improve the use of teaching strategies with various objectives, such as teaching to promote the development of student learning skills (Spiller \& Ferguson, 2011), development of research-based learning model in biology education (Haviz, 2018), teaching to improve students' cooperative skills (Haviz, 2015), and teaching to improve students' integrative skills (Haviz, Lufri, Fauzan, \& Mawardi, 2012). The teachings employ a variety of designs and methods, such as modern instructional design (Haviz, 2015) or new teaching models for the Minangkabau Surau and educational classes as non-formal education (Haviz, 2017). 
The use of multi-teaching methods is widely used to improve student learning outcomes, for example comparing the use of three methods to improve students' information skills (Suter, 2005). The use of other multi-methods is the use of mixed methods to analyze research literature in science classes (Schram, 2014). The use of more specific teaching strategies has also been written by previous researchers, such as the use of inquiry and direct instruction in the science-science class (Cobern, et al., 2010), and the influence of instruction-inquiry teaching on learning outcomes, science process skills and student attitudes Turkish elementary school (Koksal \& Berberoglu, 2014). The explanations show that there is a correlation between the method of teaching to student learning outcomes (Beausaert, Segers, \& Wiltink, 2013) and the explanations also show that the use of teaching strategies is in accordance with the content or learning materials.

Research approaches/ research designs/ research methods are the three terms that represent research and provide information about how the steps to construct research by performing certain procedures (Creswell, 2014). The subject matter in research approaches/research designs/research methods is the identification of research problems, literature review, research objectives, data collection, data analysis and reporting and evaluation of research. In the articles that report by Willison \& Pijlman (2016), the subject matter is also called research development skill (RSD). In order to master the skill well, lecturers must find a teaching strategy that matches the content. Teaching strategies that teach authentic content are lecture discussion (LD), direct instruction (DI), and guide inquiry (GI) (Eggen \& Kauchak, 2012). There are several articles that examine the use of multi-methods and / or the use of LD, DI and GI in research approaches/ research designs/research methods. For examples, Hamm, Cullen, \& Ciaravino (2013) have reported the use of inquiry-based instruction to teach methods of research to students of $4^{\text {th }}$ level. Schram
(2014) has written the use of mixed methods of content analysis of the research literature in science education. Suter (2005) has written about multiple methods: research methods in education projects at NSF1, and the use of integrative models for teaching quantitative research design (Corner, 2002).

\section{Research approaches, research designs, and research methods}

The process of research concists of six step:(1) identifyng a research problem: specifying a problem, justifying the problem, suggesting the need to study the problem for audience; (2) reviewing the literature: locating resources, selecting resources, summarizing resources; (3) specifyng a purpose for research: identifying the purpose statement, narrowing the purpose statement to research question or hypotheses; (4) collecting data: selecting individuals to study, obtaining permissions, gathering information; (5) analyzing and interpreting data: breaking down the data, representing the data, explaining the data (6) reporting and evaluating research: deciding on audiences, structuring the report and writing the report sensitively. These steps are also carried out in quantitative research. Quantitative research is an approach for testing objective theories by examining the relationship among variables (Creswell, 2014). General purpose of quantitative research is to collect and analyze the data to explain, predict, or control phenomena of interest like describe current conditions, to investigate the relationships and study causes and effects. In quantitative research the major characteristics are (1) describing a research problem through a description of trends or a need for an explanation of the relationship among variables; (2) providing a major role for the literature through suggesting the research questions to be asked and justifying the research problem and creating a need for the direction (purpose statement and research questions or hypotheses) of the study; (3) creating purpose statements, research questions, and hypotheses that are specific, narrow, measurable, and observable; (4) 
collecting numeric data from a large number of people using instruments with preset questions and responses; (5) analyzing trends, comparing groups, or relating variables using statistical analysis, and interpreting results by comparing them with prior predictions and past research and (6) writing the research report using standard, fixed structures and evaluation criteria, and taking an objective, unbiased approach (Creswell, 2012).

Teaching quantitative research design is studying and discussing about authentic scientific research articles, writing a review of a scientific research article, presenting this review to fellow-students, and discuss this review with the author of the reviewed article, writing and presenting a state-of-the-art paper, deriving hypotheses from this state-of-the-art paper, formulating a research question and developing a full research proposal (Hensel, 2012). That is called research skill development. Research skill development can be seen as an underlying principle of all education, not as something restricted to 'researchers' engaging in activities which compete with their teaching demands (Willison, 2009). Research skill development (RSD) and the research skill development-7 (RSD7) has been develop to frame research skill development about facets of research and seven levels of student autonomy on various levels(Willison \& Pijlman, 2016; Willison \& O’Regan, 2015).

\section{LD, DI and GI}

Lecturermethod was the most frequently criticized teaching method, but this method was the most widely used by teachers(Cuban, 1993). Because although easy and efficient, but this method has a number of weaknesses that cause students to become passive, uninteresting and ineffective attract students, making teachers is not check the perception and development of student understanding. However, these weaknesses were resolved by combining lecturer with discussion. Because, LD is designed to encourage high levels of social interaction, effectively retain students' attention, and teachers enable to assess the development of students' understanding (Eggen \& Kauchak, 2012). The syntax of LD is review and introduction, presentation, monitoring of knowledge, integration, presentation and close-end. DIis a models that using by teacher to combine demonstrations and explanations, exercises to ask the feedback form students to help them gain the real knowledge and skills needed for further learning (Kuhn, 2007). DI was not widely implemented and draws much criticism from some educators(McMullen \& Madelaine, 2014). But, an argument was made for the need to contemplate instructional methods within the broader context of instructional goals (Kuhn, 2007). DI was effective to overcome learning difficulties and students have low learning motivation (Kaylor \& Margaret, 2007). With a number of adaptations, DI can be successfully used on all grade levels in any material field.The syntax of DI is introduction and review, presentation, guide-task and selftask.GI is a teaching approach where teachers give students specific examples and guide students to understand the topic. This appraoch is effective for encouraging student involvement and motivation while helping them gain an in-depth understanding of the obvious topics. The step of GI is introduction, open mind, convergen and close-apllied (Eggen \& Kauchak, 2012).

The purpose of this study was to investigate the effect of LD, DI and GI on students'achievement in quantitative design research course. At IAIN Batusangkar, we have a quantitative design research course that must be taken by students at the undergraduate and master's levels. This course will equip students to solve the problems on quantitative method. We assume that an authentic and content alternative of teachings' approach, such LD, DI and Glis can be used to improve students achievement on quantitative research design. In this study, an experimental comparison of method of teachingwas use at three session of learning. At session 1, I investigated the effect ofLD to students'knowledge on quantitative research design. At session 2, I investigated the effect 
of DI to students'knowing about the quality of articlesand review thearticleson quantitative research design. At session 3, I investigated the effect of GI to students'academic writing proposol on quantitative research design.

\section{METHOD}

\section{Research Design}

I used an experimental comparison group post-test only design to prove the hypothesis "there is a significant difference of students'achievement (knowledge, knowing about the quality of articles, review thearticlesand academic writing proposol) onlundergraduates' biology education class (BEC) and master's economics class (EC)with the using of LD, DI and GI on quantitative research design". This study used 34 BECs' student (from 79 students) and 26 ECs'students (from 68 students) from who take quantitative research courses in the academic year 2016-2017at IAIN Batusangkar, West Sumatra Indonesia.

\section{Variable, Material, Instrument and Data Collection}

The independent variable was LD, DI and GI and dependent variable wasstudents' achievement (knowledge; knowing the quality of articles, review thearticlesand academic writing proposol). The students' achievement was measured by instrument of Research based Learning (RbL) (Trisoni \& Haviz, 2016). This instrument has relevancy, consistency internal and construct validity with the means scores 3.27 (valid/good). To conduct consystency internal in this experiment, I have implemented the syntax of three methods as long as 16 weeks meeting in each the class room. The same teacher and instruments have conduct the syntax of three methods in two experiment class room (BEC and EC). The students always used the computer that connext with internet to search all information about the course in the class room. I suggested the students to use the book: research design qualitative, quantitative and mixed methods approaches (Creswell,
2014) as source of context. Then, the procedur to collect the data describe as the following section.

Session 1. Investigating LD to students' knowledge on quantitative research design

At this session, I have investigatedthe use of LD to students' knowledgeon quantitative research design. I will prove the hypothesis; "there is a significant difference of students'knowledge on BEC and ECwith the using of $\mathrm{LD}$ on quantitative research design". At this session, I conducted the syntax of LD as long as $6^{\text {th }}$ week meetings in the class room. The syntax of LD: Introductions and Review; I have reviewed the previous topics and I have presented a guide for the lesson. Presentation; I have provided the information to build a systematic knowledge. Knowledge monitoring; I asked the questions informally to assess how far the students to remember and understand the information that has been given. Integration; I have given the students additional information and I asked the questions that helped the students to integrate the information already provided. End; the students did the work and I did not guide them again as they reviewed and summarized the information in the lesson. At the end of the meeting, I conducted the post-test by using the RbLs' instrument. The collected data has been analyzed by using descriptive statistics. Chi-Square test was used to determine the comparison of results in both treatment classes.

\section{Session 2. Investigating DI to students' knowingabout the quality thearticlesand review thearticleson quantitative research design}

At this session, I have investigated the use of DIto students'knowing about the quality of articlesand review the articleson quantitative design research. I will prove the hypothesis: "there is a significant difference of students'knowing about the quality the articles and review the articles on BEC and EC with the using of DI on quantitative research design". At this session, I have conducted the syntax of DI as long as 5th 
weeks meeting in the class room. The syntax of DI; Introduction and Review; I introducedthe lessons and reviewed the students' early understanding.

I have presented the new skills and explained them with high quality examples. Guided practice; the students have practiced skills with my guidance. Self-practice; the students have practiced their own skills and wrote their assignments. Furthermore, I asked the students to searching and writing a task base on the the RbLs' instrument. I have checked and assesment the level of the students' task about the quality of the articles and review thearticles. I also noted the journals where the publication of these articles, and I also classifyied the quality of journal based on the regulation of minister education of Indonesia (Directorate General of Higher Education Republic Indonesia, 2014). The collected data has been analyzed by using descriptive statistics and Chi-Square test was used to determine the comparison of results in both treatment classes.

Session 3. Investigating GI to students'academic writing proposol skill on quantitative research design

At this session, I have investigated the using of GI to students'academic writing proposol skill on quantitative design research. I will prove the hypothesis: "there is a significant difference of students'academic writing proposol skill on BEC and EC with the using of GI on quantitative research design". At this session, I have conductedthe syntaxof GI as long as 5th weeks meeting in the class room. The syntax of GI: Introduction; I have attracted students' attention and set the focus of the lesson. Open phase; I have set an example and asked the students to observe and compare the examples. Convergent; I have asked more specific questions that have been designed to guide students achieve an understanding of concepts and generalizations about writing proposal on quantitative design research. Closing and implementation; I have guided students to understand the definition of concepts or generalizations and the students apply their understanding into a new context. Furthermore, I asked the students to writing a quantitative research proposal. I have done an assessment of proposals that have been written by the students. The evaluationhas conduct by using RbLs' instrument. The collected data has been analyzed by using descriptive statistics (mean and standard deviation).

\section{RESULTS AND DISSCUSSION}

\section{Investigating LD to students'knowledge scores on quantitative design research: BEC vs. EC}

Mean (quality) for students' knowledge scores on quantitative design research with the using of LD has shown in Figure 1. Data from this study has shown that the distributions of mean (quality) for students' knowledge scores on BEC vs. EC was $\mathrm{A}(14.71 \%)-\mathrm{C}(2.941 \%)$ vs. A $(42.31 \%)$ - B+ $(3.846 \%)$. The highest mean (quality) for students' knowledge scores on BEC vs. EC wasB+ $(47.06 \%)$ vs. A (42.31\%).The lowest mean (quality) forstudents' knowledge scores on BEC vs. EC was C $(2.942 \%)$ vs. B+ $(3.846 \%)$.The Chi-Square test score has shown $\chi^{2}(71.276)>\chi^{2}$ table $\alpha(0.05 ; 0.01)$ $(15.507 ; 20.090)$. The results of this test have shown that the hypothesis (H1) was accepted. It is concluded that there was significant difference of students' knowledge on BEC and $\mathrm{EC}$ with the using of LD on quantitative research. 


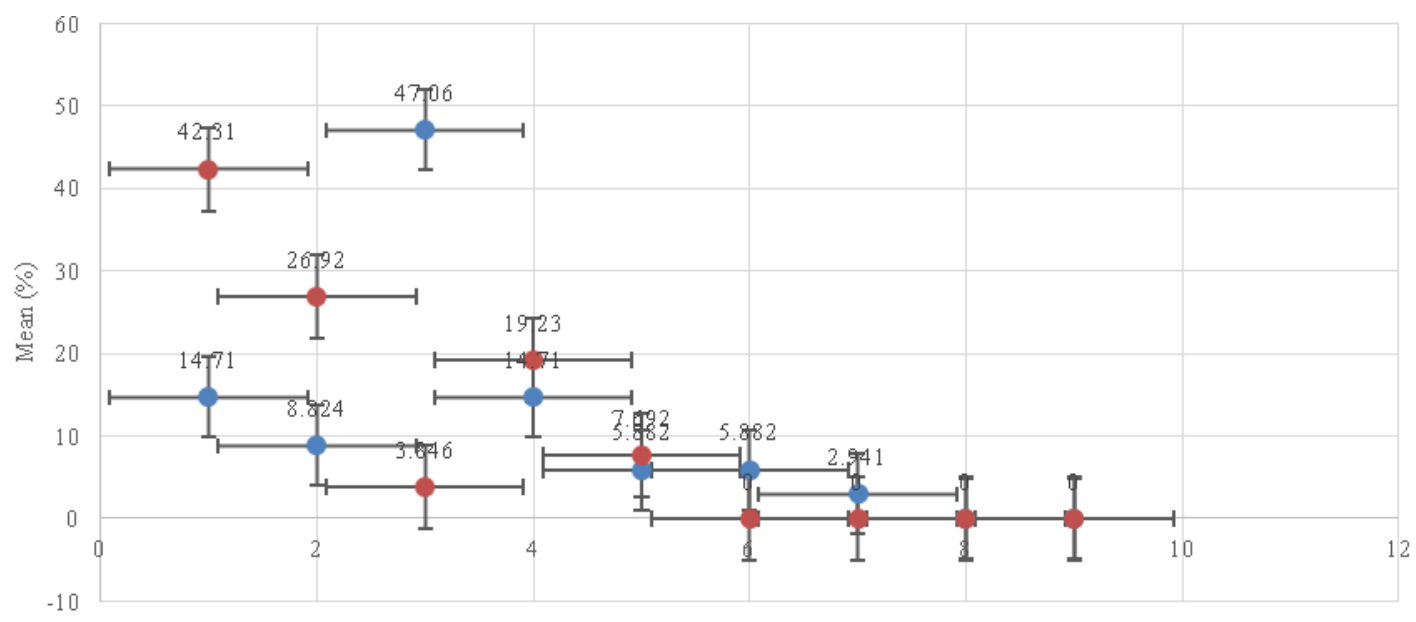

Figure 1 Descriptive statistics for investigating LD to students' knowledge scores on quantitative design research: $\mathrm{BEC}$ vs. EC

Investigating DI to students' understanding about the quality of articles scores on quantitative design research: BEC vs. EC

Mean (quality) for students'knowing about quality of articlesscores on quantitative design research with the using of DI is shown in Figure 2. Data from this study has shown that distribution of mean (quality) for students' understanding about the quality of articlesscoreson BEC vs. EC was B+ (16.7\%) to $\mathrm{D}(3.33 \%)$ vs. $\mathrm{A}(42.31 \%)$ to $\mathrm{C}+(26.92 \%)$. The highest mean (quality) for students' knowing about the quality of articles scores on BEC vs. EC wasB- $(25 \%)$ vs. A $(42.31 \%)$.The lowest (quality) forknowing about the quality of articlesscoreson BEC vs. EC was D $(3.33 \%)$ vs B $(3.846 \%)$.The ChiSquare test score has shown $\chi^{2}(28.342)>\chi^{2}$ table $\alpha(0.05 ; 0.01) \quad(15.507 ; 20.090)$. The results of this test have shown that the hypothesis (H1) was accepted. Thus it is concluded that there was significant difference of students'knowing about the quality of articles scores on BEC and EC with the using of DI on quantitative research design".

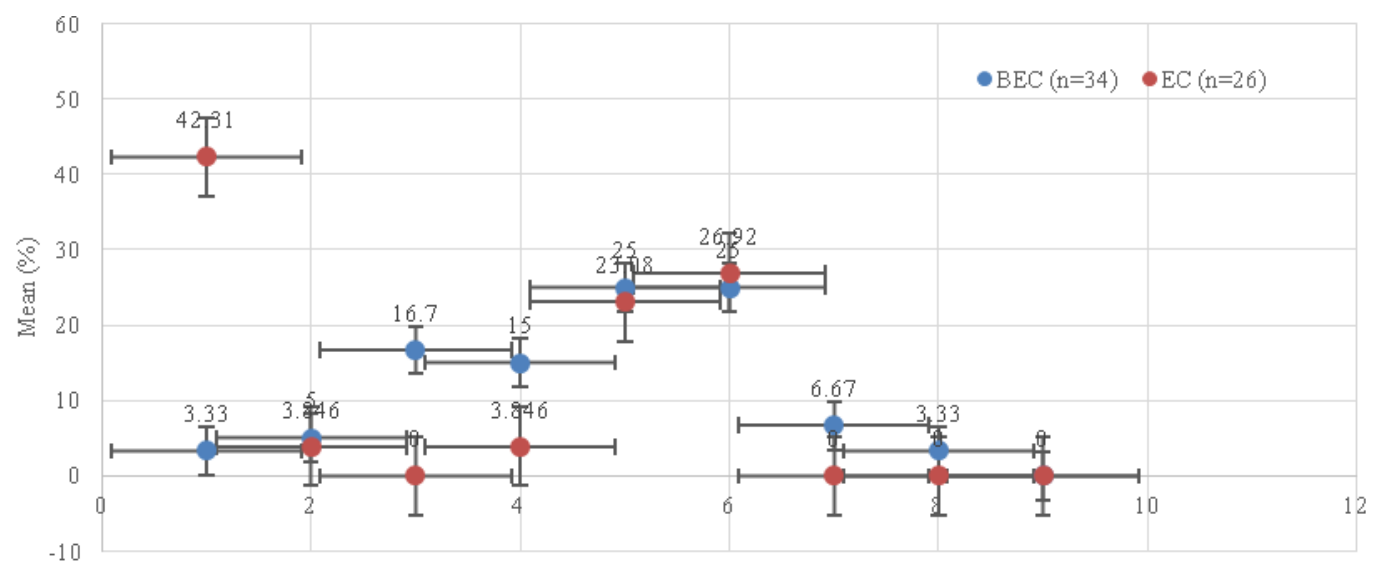


The result about the classificationof qualitys'journal based on the regulation of the minister of education Indonesiahas shown on Table 1, and the classification of articles has reviewed by students on quantitative research design has shown on Table 2. Based on the number of journals, the students on BEC vs.EChas reviewed $128(55.17 \%)$ vs. 104 $(44.83 \%)$ of journals. Based on the number of articles, the students on BEC vs. EC has reviewed 207 (58.81\&) vs. 145 (41.19\%) of articles. Based on the classification of articles on quantitative research design has reviewed by students on BEC vs. EC was 117 vs. 97 articles. Mean for descriptive research design score on BEC vs. EC was $21.37 \%$ vs. $28.87 \%$. Mean for correlational design score on BEC vs. EC was $22.22 \%$ vs. $21.65 \%$. Mean for causal-comparative design score on BEC vs. EC was $12.82 \%$ vs. $9.28 \%$. Mean for experimental design score on BEC vs. EC was $36.75 \%$ vs $30.08 \%$. Mean for singlesubject design score on BEC vs. EC was $6.84 \%$ vs. $4.12 \%$.

Table 1. The classification of qualitys' journal based on the regulation of the minister of education Indonesia

\begin{tabular}{|c|c|c|c|c|}
\hline \multirow[b]{2}{*}{ Classification } & \multicolumn{2}{|c|}{ Number of Journal } & \multicolumn{2}{|c|}{ Number of Articles } \\
\hline & $\begin{array}{c}\text { BEC } \\
(n=34)\end{array}$ & $\mathrm{EC}(\mathrm{n}=26)$ & $\begin{array}{c}\text { BEC } \\
(n=34)\end{array}$ & $\begin{array}{c}\mathrm{EC} \\
(\mathrm{n}=26)\end{array}$ \\
\hline $\begin{array}{l}\text { International journal (index by an international of } \\
\text { data base and having impact factor) }\end{array}$ & 18 & 14 & 22 & 18 \\
\hline $\begin{array}{l}\text { International journal (index by an international of } \\
\text { database and not having impact factor) }\end{array}$ & 34 & 22 & 38 & 28 \\
\hline International journal except no. 1 and no 2 & 22 & 17 & 28 & 25 \\
\hline Indonesian journal of accredited by Kemenristekdikti & 6 & 8 & 14 & 12 \\
\hline Indonesian journal index by DOAJ & 14 & 18 & 35 & 22 \\
\hline $\begin{array}{l}\text { English language journal or using United Nation } \\
\text { language index by DOAJ }\end{array}$ & 3 & 6 & 22 & 9 \\
\hline Indonesian journal or with Indonesian language & 23 & 14 & 34 & 22 \\
\hline $\begin{array}{l}\text { Journal has written on United Nation language but its } \\
\text { not categorized as international academic journal }\end{array}$ & 8 & 5 & 14 & 9 \\
\hline Total & 128 & 104 & 207 & 145 \\
\hline
\end{tabular}

Table 2. The classification of articles has reviewed by students on quantitative research design

\begin{tabular}{|c|c|c|c|}
\hline \multirow[b]{2}{*}{ Type of Design } & & \multicolumn{2}{|c|}{ Number of articles } \\
\hline & & $\begin{array}{c}\text { BEC } \\
(n=34)\end{array}$ & $\mathrm{EC}(n=26)$ \\
\hline Descriptive & & 25 & 28 \\
\hline Correlational & & 26 & 21 \\
\hline Causal-Comparative & & 15 & 9 \\
\hline Experimental & & 43 & 35 \\
\hline Single-Subject & & 8 & 4 \\
\hline & Total & 117 & 97 \\
\hline
\end{tabular}

\section{Investigating DI to students'review the articlesscores on quantitative design research: BECvs. EC}

Mean (quality) for students' review the articles scores on quantitative design research with the using of DI is shown in Figure 3. Data from this study has shown that the distribution of mean (quality) for students' review the articles scores on BEC vs. EC was A $(16.67 \%)$ to $\mathrm{E}(11.11 \%)$ vs. A $(73.08 \%)$ to $\mathrm{C}+(7.692 \%)$. The highest mean (quality) for students' review the articles scores on BEC vs. EC was A (16.67\%) vs. A (73.08\%). The lowest (quality) for students' review the articles scores on BEC vs. EC was C+ $(5.55 \%)$ vs $\mathrm{C}+(7.962 \%)$. The Chi-Square test score has $\operatorname{shown} \chi^{2}(203.12)>\chi^{2}$ table 
$\alpha(0.05 ; 0.01)(15.507 ; 20.090)$. The result of this test has shown that the hypothesis (H1) was accepted. Thus, it is concluded that there was significant difference of students' review the articles scores on BEC and EC with the using of DI on quantitative research design".

Table 3. Descriptive statistics for students' academic writing proposol scores on quantitative design research: BEC vs. EC

\begin{tabular}{|c|c|c|c|c|c|c|c|c|c|c|}
\hline & \multicolumn{2}{|c|}{ 4-Above Standard } & \multicolumn{2}{|c|}{ 3-At Standard } & \multicolumn{2}{|c|}{$\begin{array}{l}\text { 2-Approaching } \\
\text { Standard }\end{array}$} & \multicolumn{2}{|c|}{ 1-Below Standard } & \multicolumn{2}{|c|}{ 0-Unacceptable } \\
\hline & $\begin{array}{c}\text { BEC } \\
(n=34)\end{array}$ & $\begin{array}{c}\text { EC } \\
(n=26)\end{array}$ & $\begin{array}{c}\text { BEC } \\
(n=34)\end{array}$ & $\begin{array}{c}\text { EC } \\
(n=26)\end{array}$ & $\begin{array}{c}\text { BEC } \\
(n=34)\end{array}$ & $\begin{array}{c}\text { EC } \\
(n=26)\end{array}$ & $\begin{array}{c}\text { BEC } \\
(n=34)\end{array}$ & $\begin{array}{c}\text { EC } \\
(n=26)\end{array}$ & $\begin{array}{c}\text { BEC } \\
(n=34)\end{array}$ & $\begin{array}{c}\text { EC } \\
n=26)\end{array}$ \\
\hline & $\mathrm{M} \pm \mathrm{SD}$ & $\mathrm{M} \pm \mathrm{SD}$ & $\mathrm{M} \pm \mathrm{SD}$ & $\mathrm{M} \pm \mathrm{SD}$ & $\mathrm{M} \pm \mathrm{SD}$ & $\mathrm{M} \pm \mathrm{SD}$ & $\mathrm{M} \pm \mathrm{SD}$ & $\mathrm{M} \pm \mathrm{SD}$ & $\mathrm{M} \pm \mathrm{SD}$ & $\begin{array}{l}\mathrm{M} \pm \\
\mathrm{SD}\end{array}$ \\
\hline A & $\begin{array}{l}17.65 \pm \\
8.236\end{array}$ & $\begin{array}{c}38.46 \pm \\
20.13\end{array}$ & $\begin{array}{c}23.53 \pm \\
10.98\end{array}$ & $\begin{array}{c}50 \pm \\
26.16\end{array}$ & $\begin{array}{c}35.3 \pm \\
16.47\end{array}$ & $\begin{array}{c}11.54 \pm \\
6.038\end{array}$ & $\begin{array}{c}11.76 \pm \\
5.490\end{array}$ & $0 \pm 0$ & $\begin{array}{c}11.76 \pm \\
5.49\end{array}$ & $0 \pm 0$ \\
\hline B. 1 & $\begin{array}{c}17.65 \pm \\
8.236\end{array}$ & $\begin{array}{c}30.77 \pm \\
16.1\end{array}$ & $\begin{array}{c}26.47 \\
\pm 12.35\end{array}$ & $\begin{array}{l}53.8 \pm \\
28.18\end{array}$ & $\begin{array}{c}32.4 \pm \\
15.1\end{array}$ & $\begin{array}{l}17.64 \pm \\
8.235\end{array}$ & $\begin{array}{l}17.64 \pm \\
8.235\end{array}$ & $0 \pm 0$ & $\begin{array}{l}5.882 \pm \\
2.745\end{array}$ & $0 \pm 0$ \\
\hline B. 2 & $\begin{array}{c}20.59 \pm \\
9.608\end{array}$ & $\begin{array}{c}38.46 \pm \\
20.13\end{array}$ & $\begin{array}{c}20.59 \pm \\
9.608\end{array}$ & $\begin{array}{l}46.2 \pm \\
24.15\end{array}$ & $\begin{array}{c}29.4 \pm \\
13.73\end{array}$ & $\begin{array}{c}7.692 \pm \\
4.025\end{array}$ & $\begin{array}{c}23.52 \pm \\
10.98\end{array}$ & $\begin{array}{l}7.69 \pm \\
4.025\end{array}$ & $\begin{array}{c}5.882 \pm \\
2.745\end{array}$ & $0 \pm 0$ \\
\hline B. 3 & $\begin{array}{c}20.59 \pm \\
9.608\end{array}$ & $\begin{array}{c}30.77 \pm \\
16.1\end{array}$ & $\begin{array}{c}26.47 \pm \\
12.35\end{array}$ & $\begin{array}{c}50 \pm \\
26.16\end{array}$ & $\begin{array}{c}26.5 \\
\pm 12.35\end{array}$ & $\begin{array}{c}19.23 \pm \\
10.06\end{array}$ & $\begin{array}{c}17.64 \pm \\
8.235\end{array}$ & $0 \pm 0$ & $\begin{array}{c}8.823 \pm \\
4.118\end{array}$ & $0 \pm 0$ \\
\hline C. 1 & $\begin{array}{c}35.29 \pm \\
16.47\end{array}$ & $\begin{array}{l}42.31 \pm \\
22.14\end{array}$ & $\begin{array}{c}29.41 \pm \\
13.73\end{array}$ & $\begin{array}{l}42.3 \pm \\
22.14\end{array}$ & $\begin{array}{c}26.5 \pm \\
12.35\end{array}$ & $\begin{array}{l}15.38 \pm \\
8.05\end{array}$ & $\begin{array}{l}2.941 \pm \\
1.372\end{array}$ & $0 \pm 0$ & $\begin{array}{l}5.882 \pm \\
2.745\end{array}$ & $0 \pm 0$ \\
\hline C. 2 & $\begin{array}{c}23.53 \pm \\
10.98\end{array}$ & $\begin{array}{l}38.46 \pm \\
20.13\end{array}$ & $\begin{array}{c}26.47 \pm \\
12.35\end{array}$ & $\begin{array}{c}50 \pm \\
26.16\end{array}$ & $\begin{array}{l}41.2 \pm \\
19.22\end{array}$ & $\begin{array}{c}11.54 \pm \\
6.038\end{array}$ & $\begin{array}{l}5.882 \pm \\
2.745\end{array}$ & $0 \pm 0$ & $\begin{array}{l}2.941 \pm \\
1.373\end{array}$ & $0 \pm 0$ \\
\hline C. 3 & $\begin{array}{c}23.53 \pm \\
10.98\end{array}$ & $\begin{array}{c}30.77 \pm \\
16.1\end{array}$ & $\begin{array}{c}26.47 \pm \\
12.35\end{array}$ & $\begin{array}{l}46.2 \pm \\
24.15\end{array}$ & $\begin{array}{c}44.1 \pm \\
20.59\end{array}$ & $\begin{array}{c}15.38 \pm \\
8.05\end{array}$ & $0 \pm 0$ & $\begin{array}{l}7.69 \pm \\
4.025\end{array}$ & $\begin{array}{c}5.882 \pm \\
2.745\end{array}$ & $0 \pm 0$ \\
\hline D. 1 & $\begin{array}{c}26.47 \pm \\
12.35\end{array}$ & $\begin{array}{c}42.31 \pm \\
22.14\end{array}$ & $\begin{array}{c}23.53 \pm \\
10.98\end{array}$ & $\begin{array}{l}46.2 \pm \\
24.15\end{array}$ & $\begin{array}{c}17.6 \pm \\
8.236\end{array}$ & $\begin{array}{c}11.54 \pm \\
6.038\end{array}$ & $\begin{array}{c}23.52 \pm \\
10.98\end{array}$ & $0 \pm 0$ & $\begin{array}{c}8.823 \pm \\
4.118\end{array}$ & $0 \pm 0$ \\
\hline D. 2 & $\begin{array}{c}29.41 \pm \\
13.73\end{array}$ & $\begin{array}{l}53.85 \pm \\
28.18\end{array}$ & $\begin{array}{c}20.59 \pm \\
9.608\end{array}$ & $\begin{array}{l}38.5 \pm \\
20.13\end{array}$ & $\begin{array}{c}35.3 \pm \\
16.47\end{array}$ & $\begin{array}{l}7.692 \pm \\
4.025\end{array}$ & $\begin{array}{c}8.823 \pm \\
4.117\end{array}$ & $0 \pm 0$ & $\begin{array}{l}5.882 \pm \\
2.745\end{array}$ & $0 \pm 0$ \\
\hline E.1 & $\begin{array}{c}35.29 \pm \\
16.47\end{array}$ & $\begin{array}{c}42.31 \pm \\
22.14\end{array}$ & $\begin{array}{c}20.59 \pm \\
9.608\end{array}$ & $\begin{array}{l}46.2 \pm \\
24.15\end{array}$ & $\begin{array}{c}32.4 \pm \\
15.1\end{array}$ & $\begin{array}{c}11.54 \pm \\
6.038\end{array}$ & $\begin{array}{c}11.76 \pm \\
5.490\end{array}$ & $0 \pm 0$ & $0 \pm 0$ & $0 \pm 0$ \\
\hline E. 2 & $\begin{array}{c}29.41 \pm \\
13.73\end{array}$ & $\begin{array}{l}42.31 \pm \\
22.14\end{array}$ & $\begin{array}{c}35.29 \pm \\
16.47\end{array}$ & $\begin{array}{c}30.8 \pm \\
16.1\end{array}$ & $\begin{array}{l}29.4 \pm \\
13.73\end{array}$ & $\begin{array}{c}15.38 \pm \\
8.05\end{array}$ & $\begin{array}{l}5.882 \pm \\
2.745\end{array}$ & $\begin{array}{c}11.5 \pm \\
6.038\end{array}$ & $0 \pm 0$ & $0 \pm 0$ \\
\hline E. 3 & $\begin{array}{c}26.47 \pm \\
12.35\end{array}$ & $\begin{array}{l}46.15 \pm \\
24.15\end{array}$ & $\begin{array}{c}41.18 \pm \\
19.22\end{array}$ & $\begin{array}{c}30.8 \pm \\
16.1\end{array}$ & $\begin{array}{l}26.5 \pm \\
12.35\end{array}$ & $\begin{array}{l}7.692 \pm \\
4.025\end{array}$ & $\begin{array}{l}5.882 \pm \\
2.745\end{array}$ & $\begin{array}{l}15.4 \pm \\
8.05\end{array}$ & $0 \pm 0$ & $0 \pm 0$ \\
\hline F.1 & $\begin{array}{c}35.29 \pm \\
16.47\end{array}$ & $\begin{array}{l}42.31 \pm \\
22.14\end{array}$ & $\begin{array}{c}32.35 \pm \\
15.1\end{array}$ & $\begin{array}{l}38.5 \pm \\
20.13\end{array}$ & $\begin{array}{l}20.6 \pm \\
9.608\end{array}$ & $\begin{array}{c}11.54 \pm \\
6.038\end{array}$ & $\begin{array}{c}11.76 \pm \\
5.490\end{array}$ & $\begin{array}{l}7.69 \pm \\
4.025\end{array}$ & $0 \pm 0$ & $0 \pm 0$ \\
\hline F. 2 & $\begin{array}{c}17.65 \pm \\
8.236\end{array}$ & $\begin{array}{c}61.54 \pm \\
32.2\end{array}$ & $\begin{array}{c}35.29 \pm \\
16.47\end{array}$ & $\begin{array}{l}26.9 \pm \\
14.09\end{array}$ & $\begin{array}{l}26.5 \pm \\
12.35\end{array}$ & $\begin{array}{c}7.692 \pm \\
4.025\end{array}$ & $\begin{array}{c}14.70 \pm \\
6.863\end{array}$ & $\begin{array}{l}3.85 \pm \\
2.013\end{array}$ & $\begin{array}{c}5.882 \pm \\
2.745\end{array}$ & $0 \pm 0$ \\
\hline F. 3 & $\begin{array}{c}38.24 \pm \\
17.84\end{array}$ & $\begin{array}{c}42.31 \pm \\
22.14\end{array}$ & $\begin{array}{c}23.53 \pm \\
10.98\end{array}$ & $\begin{array}{l}42.3 \pm \\
22.14\end{array}$ & $\begin{array}{c}23.5 \pm \\
10.98\end{array}$ & $\begin{array}{c}11.54 \pm \\
6.038\end{array}$ & $\begin{array}{c}11.76 \pm \\
5.490\end{array}$ & $\begin{array}{l}3.85 \pm \\
2.013\end{array}$ & $\begin{array}{c}2.941 \pm \\
1.373\end{array}$ & $0 \pm 0$ \\
\hline
\end{tabular}

Note: A.1. title; B. Identifying a research problem: B.1. Specifiyng a problem, B.2. Justifying the problem and B.3. Suggesting the need to study the problem for audience; C. Reviewing the literature: C.1. Locating resources, C.2. Selecting resources and C.3. Summarizing resources. D. Specifying a purpose for research: D.1. Identifying the purpose statement and D.2. Narrowing the purpose statement to research question or hypotheses. E. Collecting data: E.1. Selecting individuals to study, E.2. Obtaining permissions and E.3. Gathering information. F. Analyzing and interpreting data: F.1. Breaking down the data, F.2. Representing the data and F.3. Explaining the data

\section{RESULTS AND DISCUSSION}

The result of this study has shown that students'achievement on EC is better than BEC. The result of an experimental comparison group post-test only design has shown that the hypothesis is accepted, or there was a significant difference of students' achievement (knowledge, knowing about the quality of articles, review the articles and academic writing proposol) on BEC and EC with the using of LD, DI and GI on quantitative research design. The finding of this study has shown that the use of multiple 
method (LD, DI and GI) is effective to students' achievementon quantitative research design in higher education. This finding was indicated that the lecture method is the most common form of teaching in institutions of higher education throughout the world (Behr, 2006). When designing and implementing courses in higher education, the choice of teaching method should be linked closely to educational objectives and project work and tutorials are more likely to meet the important objectives than lectures (Liow, Betts, \& Lit, 2006).The state of the art of teaching research methods has identified that indicate some new agendas for research on teaching research methods in the social sciences (Wagner, Garner, \& Kawulich, 2011). The effectiveness of lectures in carrying out various functions is discussed with reference to some recent educational research (Pritchard, 2010). Knowledge of research methods is regarded as crucial and is viewed as a challenging area for lecturers and students (Gray, et al., 2015).

This finding was also shown that the structure and sequence of DI is the creative application of empirically verified instructional design principles (Moore, 2006). Although re-teaching is assumed integral to effective teaching, learning, formative assessment, but effective re-teaching is scantly described in pedagogical literature and has been neglected in empirical research (Bellert, 2015). As viable teaching method (Demant \& Yates, 2010), aspect of DI instruction in this study was relevance with other finding studies. For example, DI instruction attract the most criticism has broken down to determine just what it is that educators do not like about it (McMullen \& Madelaine, 2014) and DI also was usedto introduce the skill of determining source reliability in a fifth-grade unit on immigration in American history (Reagan, 2010).

This finding was also shown that using of conceptual framework for inquiry-based learning can usedfor pedagogical design and research/evaluation (Levy \& Petrulis, 2012). There is a positive significant relationship between inquiry-based learning is with outcomes and student satisfaction (Gómez, Martínez, \& Miranda, 2015). In other study has shown that GI was help students determine how to divide tasks amongst themselves and subsequently jump to higher levels of discourse (Balgopal, Casper, Atadero, \& Hernandez, 2017). Inquiry based learning is also practiced in a wide range of disciplines, in both undergraduate and postgraduate coursework programs, in smaller and larger classes, and in universities which are more and less research intensive (Aditomo, Goodyear, Bliuc, \& Ellis, 2011). Scientific attitudes and stress students in one school benefited from guided inquiry (Bunterm, et al., 2014).At others context, GI based instruction to teach research method was guide teachers and students through class research that would develop students' inquiry skill (Hamm, Cullen, \& Ciaravino, 2013).

The result of this study has shown that researchs'quality is positively related with teachings' quality (Cadez, Dimovski, \& Groff, 2017). There is clearly a linkage between research and teaching at a global level, it needs nurturing locally(Tight, 2016). There is benefit of academic research and teaching quality identified by undergraduate and postgraduate students (Lindsay, Breen, \& Jenkins, 2010). In others context, research informed teaching has a positive impact on students' learning and should be promoted for taught-postgraduate education of maritime law and integrated into the learning program systematically (Zhu \& Pan, 2017). Students indicated that lecturers who had published would be seen as more credible and would link their research activity to the learning experience more effectively (Schofield \& Burton, 2015).

The finding of this study has shown thatthe RSDs' skill has achieved on teaching quantitative research design. The students achievement of this study, such knowledge, students' knowing, quality and review the articles and review the thesis on quantitative design research was linked and matched with facets of research students (embark \& clarity, find \& generate, evaluate \&reflect, organize 
\& manage, analysis \& synthesis, communicate \& apply) and students' autonomy level (prescribed research, bounded research, scaffolding research, self-initiated research, open research, adopted research and enlarging research) (Willison \& Pijlman, 2016). RSDs' skill is also studying and discussing authentic scientific research articles; writing a review of a scientific research article, presenting this review to fellow-students, and discuss this review with the author of the reviewed article, writing and presenting a state-of-the-art paper, deriving hypotheses from this state-of-the-art paper, formulating a research question and developing a full research proposal (Hensel, 2012). The finding of this study shows that all students and academics stated the benefits of the use of the researcher skill development framework in undergraduate. The implication of the articles shows that when adapted to the context, whole of degree research skill development may enable developing countries to have more students (Willison, 2012; Willison \& O'Regan, 2007; Willison, Pierce, \& Ricci, 2009).

\section{CONCLUSION AND RECOMMENDATION}

The result of the study has shown that the use of LD, DI and GIwas effect to students' achievement on quantitative research design. In this study, the use of an experimental comparison of method of teachingwas effective at three session of learning. At session 1, the hypothesis "there was significant difference of students' knowledge on BEC and EC with the using of LD on quantitative research design" was proved. At session 2, the hypothesis "there was significant difference of students'knowing about quality of articlesscores on BEC and EC with the using of DI on quantitative research design" was proved. At session 3, the hypothesis "there was difference of students'academic writing proposol scores on BEC and EC with the using of GI on quantitative research design" was proved. In conclusion, there was significant difference of students'achievement on undergraduate biology education class (BEC) and master's economic class (EC) on quantitative research design with the using of LD, DI and GI. Recommendation of this study is the three methods (LD, DI and GI) still can be used by teachers in various context and courses, especially on quantitative design research course

\section{REFERENCES}

Aditomo, A., Goodyear, P., Bliuc, A. M., \& Ellis, R. A. (2011). Inquiry-based learning in higher education: principal forms, educational objectives, and disciplinary variations. Studies in Higher Education, 38(9), 1239-1258. Retrieved from http://dx.doi.org/10.1080/03075079.20 11.616584

Balgopal, M. M., Casper, A. A., Atadero, R. A., \& Hernandez, K. E. (2017). Responses to different types of inquiry prompts: college students' discourse, performance, and perceptions of group work in an engineering class. International Journal of Science Education, 1625-1647. Retrieved from http://dx.doi.org/10.1080/09500693.20 17.1346847

Beausaert, S. A., Segers, M. S., \& Wiltink, D. W. (2013). The influence of teachers' teaching approaches on students' learning approaches: the student perspective. Educational Research, 55(1), 1-15. Retrieved from http://dx.doi.org/10.1080/00131881.20 13.767022Behr, A. L. (2006). Exploring the lecture method: An empirical study. Studies in Higher Education, 13(2), 189-200. Retrieved from

http://dx.doi.org/10.1080/0307507881 2331377866

Bellert, A. (2015). Effective re-teaching. Australian Journal of Learning Difficulties, 20(2), 163-183. Retrieved from 
http://dx.doi.org/10.1080/19404158.20 15.1089917

Brew, A. (2010). Teaching and research: New relationships and their implications for inquiry-based teaching and learning in higher education. Higher Education Research \& Development, 22(1), 3-18. Retrieved from http://dx.doi.org/10.1080/0729436032 000056571

Bunterm, T., Lee, K., Kong, J. L., Srikoon, S., Vangpoomyai, P., Rattanavongsa, J., \& Rachahoon, G. (2014). Do different levels of inquiry lead to different learning outcomes? A comparison between guided and structured inquiry. International Journal of Science Education, 36(12), 19371959. Retrieved from http://dx.doi.org/10.1080/09500693.20 14.886347

Cadez, S., Dimovski, V., \& Groff, M. Z. (2017). Research, teaching and performance evaluation in academia: the salience of quality. Studies in Higher Education, 42(8), 1455-1473. Retrieved from http://dx.doi.org/10.1080/03075079.20 15.1104659

Cobern, W. W., Schuster, D., Adams, B., Applegate, B., Skjold, B., \& Undreiu, A. (2010). Experimental comparison of inquiry and direct instruction in science. Research in Science \& Technological Education, 28(1), 8196. Retrieved from http://dx.doi.org/10.1080/0263514090 3513599

Corner, P. D. (2002). An integrative model for teaching quantitative research design. Journal of Management Education, 26(6), 671-692. Retrieved from https://doi.org/10.1177/105256290223 8324

Creswell, J. W. (2012). Educational research: planning, conducting and evaluating quatitative and qualitative research (4th ed.). Boston: Pearson Education, Inc. Retrieved from http://www.pearsonhighered.com

Creswell, J. W. (2014). Research design: qualitative, quantitative, and mixed methods approaches (4th ed.). California: SAGE Publication,Inc.

Cuban, L. (1993). How teachers taught: Constancy and change in American classrooms, 1880-1990 (2nd ed.). New York: Teachers College Press.

Demant, M. S., \& Yates, G. C. (2010). Primary teachers' attitudes toward the direct instruction construct. Educational Psychology An International Journal of Experimental Educational Psychology, 23(5), 483489. Retrieved from http://dx.doi.org/10.1080/0144341032 000123741

Directorate General of Higher Education Republic Indonesia. (2014). Pedoman Operasional Penilaian Angka Kredit Kenaikan Pangkat/Jabatan Akademik Dosen. Jakarta: Kementerian Pendidikan dan Kebudayaan.

Eggen, P., \& Kauchak, D. (2012). Strategies and models for teachers: teaching content and thinking skills (6th ed.). Boston: Pearson Education, Inc.

European University Association. (2016). EUA Work Programme 2016/2017. Brussels: European University Association. Retrieved from http://www.eua.be/Libraries/euadocuments/workprogramme_2016_17arial.pdf?sfvrsn= 0

Gómez, J. L., Martínez, I. R., \& Miranda, M. E. (2015). Measuring the impact of inquiry-based learning on outcomes and student satisfaction. Assessment \& Evaluation in Higher Education, 40(8), 1050-1069. Retrieved from 
http://dx.doi.org/10.1080/02602938.20 14.963836

Gray, C., Turner, R., Sutton, C., Petersen, C., Stevens, S., Swain, J., . . . Thackerey, D. (2015). Research methods teaching in vocational environments: developing critical engagement with knowledge?. Journal of Vocational Education \& Training, 67(3), 274293. Retrieved from http://dx.doi.org/10.1080/13636820.20 15.1050443

Hamm, E. M., Cullen, R., \& Ciaravino, M. (2013). Using inquiry-based instruction to teach research methods to 4th-grade students in an urban setting. Childhood Education, 89(1), 34-39. Retrieved from http://dx.doi.org/10.1080/00094056.20 13.757522

Hara, K. (1997). A comparison of three methods of instruction for acquiring information skills. Educational Research, 39(3), 271-286. Retrieved from

http://dx.doi.org/10.1080/0013188970 390303

Haviz, M. (2015). Cooperative learning model on developmental of biology. American Journal Educational Research, 3(10), 1298-1304. doi:10.12691/education-3-10-14

Haviz, M. (2015). Modern instructional design on educational research: how to use the adaptive systems on instructional of biology. International conference on Mathematics, Science, Education and Technology (Icomset) Held on 22 october 2015 (pp. 287301). Padang: Faculty of Matehmatics and Science State University of Padang.

Haviz, M. (2017). Designing and developing a new model of education surau and madrasah minangkabau (SMM).
Jurnal Pendidikan Islam, 6(1), 79100. doi:10.14421/jpi.2017.61.79-100

Haviz, M. (2018). Development of researchbased learning model in biology education: What is relevance, concystency and practicality? Journal of Education and Learning (EduLearn), 12(1), 101-107. Retrivied from

http://journal.uad.ac.id/index.php/Edu Learn/article/view/6555

Haviz, M., Lufri, Fauzan, A., \& Efendi, Z. M. (2012). Model pembelajaran integratif pada biologi perkembangan hewan: analisi kebutuhan pengembangan. Ta'dib, 15(1), 1-14.

Healey, M. (2007). Linking research and teaching to benefit student learning. Journal of Geography in Higher Education, 29(2), 183-201. Retrieved from

http://dx.doi.org/10.1080/0309826050 0130387

Hensel, N. (2012). Characteristics of excellence in undergraduate research. Washington, DC: The Council on Undergraduate Research (CUR).

Kaylor, M., \& Margaret, F. M. (2007). Increasing academic motivation in culturally and linguistically diverse students from low socioeconomic backgrounds. Journal of Advanced Academics, 19, 66-89.

Koksal, E. A., \& Berberoglu, G. (2014). The effect of guided-inquiry instruction on 6th grade Turkish students' achievement, science process skills, and attitudes toward science. International Journal of Science Education, 36(1), 66-78. Retrieved from

http://dx.doi.org/10.1080/09500693.20 12.721942

Kuhn, D. (2007). Is direct instruction an answer to the right question? 
Educational Psychologist, 42(2), 109113. Retrieved from http://dx.doi.org/10.1080/0046152070 1263376

Levy, P., \& Petrulis, R. (2012). How do firstyear university students experience inquiry and research, and what are the implications for the practice of inquiry-based learning? Studies in Higher Education, 37(1), 85-101. Retrieved from http://dx.doi.org/10.1080/03075079.20 10.499166

Lindsay, R., Breen, R., \& Jenkins, A. (2010). Academic research and teaching quality: The views of undergraduate and postgraduate students. Studies in Higher Education, 27(3), 309-327. Retrieved from http://dx.doi.org/10.1080/0307507022 0000699

Liow, S. R., Betts, M., \& Lit, J. K. (2006). Course design in higher education: A study of teaching methods and educational objectives. Studies in Higher Education, 65-79. Retrieved from

http://dx.doi.org/10.1080/0307507931 2331382468

McMullen, F., \& Madelaine, A. (2014). Why is there so much resistance to direct instruction? Australian Journal of Learning Difficulties, 19(2), 137-151. Retrieved

from http://dx.doi.org/10.1080/19404158.20 14.962065

Moore, J. (2006). Direct Instruction: a model of instructional design. Educational Psychology: An International Journal of Experimental Educational Psychology, 6(3), 201-229. Retrieved from

http://dx.doi.org/10.1080/0144341860 060301

Pritchard, D. (2010). Where learning starts? A framework for thinking about lectures in university mathematics.
International Journal of Mathematical Education in Science and Technology, 41(5), 609-623. Retrieved from http://dx.doi.org/10.1080/0020739100 3605254

Reagan, R. (2010). Direct instruction in skillful thinking in fifth-grade american history. The Social Studies, 99(5), 217-222. Retrieved from http://dx.doi.org/10.3200/TSSS.99.5.2 17-222

Schofield, C., \& Burton, F. L. (2015). An investigation into higher education student and lecturer views on research publication and their interest in the production of a college partnership science journal. Innovations in Education and Teaching International, 52(3), 265-276. Retrieved from http://dx.doi.org/10.1080/14703297.20 13.808405

Schram, A. B. (2014). A mixed methods content analysis of the research literature in science education. International Journal of Science Education, 36(15), 2619-2638. doi:10.1080/09500693.2014.908328

Spiller, D., \& Ferguson, P. B. (2011). Teaching strategies to promote the development of students' learning skills. Waikato.

Suter, L. E. (2005). Multiple methods: research methods in education projects at NSF1. International Journal of Research \& Method in Education, 28(2), 171-181. Retrieved from http://dx.doi.org/10.1080/0140672050 0256244

Tight, M. (2016). Examining the research/teaching nexus. European Journal of Higher Education, 6(4), 293-311. Retrieved from http://dx.doi.org/10.1080/21568235.20 16.1224674 
Trisoni, R., \& Haviz, M. (2016). Designing and developing research based learning model on biology education. Batusangkar: LPPM IAIN Batusangkar.

Wagner, C., Garner, M., \& Kawulich, B. (2011). The state of the art of teaching research methods in the social sciences: towards a pedagogical culture. Studies in Higher Education, 36(1), 75-88. Retrieved from http://dx.doi.org/10.1080/0307507090 3452594

Willison, J. (2009). A handbook for research skill development and assessment in the curriculum. Adelaide: University of Adelaide.

Willison, J. (2012). When academics integrate research skill development in the curriculum. Higher Education Research \& Development, 31(6), 905919. Retrieved from http://dx.doi.org/10.1080/07294360.20 12.658760

Willison, J., \& O'Regan, K. (2007). Commonly known, commonly not known, totally unknown: a framework for students becoming researchers.
Higher Education Research and Development, 26(4), 393-410.

Willison, J., \& O'Regan, K. (2015). Research skill development framework.

Willison, J., \& Pijlman, F. B. (2016). PhD prepared: research skill development across the undergraduate years. International Journal for Researcher Development, 7(1), 63-83. Retrieved from https://doi.org/10.1108/IJRD-072015-0018

Willison, J., Pierce, E., \& Ricci, M. (2009). Towards student autonomy in literature and feild research. the Higher Education Research and Development Conference. Darwin.

Zhu, L., \& Pan, W. (2017). Application of research-informed teaching in the taught-postgraduate education of maritime law. Innovations in Education and Teaching International, 54(5), 428-437. Retrieved from http://dx.doi.org/10.1080/14703297.20 15.1102080 